\title{
RISK FACTORS AFFECTING FATAL VERSUS NON-FATAL ROAD TRAFFIC ACCIDENTS: THE CASE OF KARS PROVINCE, TURKEY
}

\author{
Ali Kemal Çelik ${ }^{1}$, Ötüken Senger ${ }^{2}$ \\ ${ }^{1}$ Atatürk University, Faculty of Economics and Administrative Sciences, Department of Quantitative \\ Methods, 25240, Erzurum, Turkey \\ ${ }^{2}$ Kafkas University, Faculty of Economics and Administrative Sciences, Department of Quantitative \\ Methods, 36100, Kars, Turkey
}

Received 6 December 2013; accepted 30 June 2014

\begin{abstract}
The aim of this paper is to determine risk factors affecting the fatal versus non-fatal accidents in a rural region of Turkey, during 2008-2012, considering variables associated with the individual, the environment, and the motor vehicle. A retrospective study was conducted by obtaining the data from the traffic police road accident reports between 2008 and 2012 . A stepwise logistic regression analysis was performed to analyze the data and critical factors that contributed significantly to fatal versus non-fatal traffic accidents. The results revealed that the driver's age $(\mathrm{OR}=1.09 ; 90 \% \mathrm{CI}=1.05-1.14)$, clear weather $(\mathrm{OR}=0.11 ; 90 \% \mathrm{CI}$ $=0.02-0.65)$, winter season $(\mathrm{OR}=0.16 ; 90 \% \mathrm{CI}=0.03-0.75)$, straight $(\mathrm{OR}=0.22 ; 90 \%$ $\mathrm{CI}=0.05-0.91)$ or slight road curve $/$ bend $(\mathrm{OR}=0.17 ; 90 \% \mathrm{CI}=0.04-0.83)$, the driver's education $(\mathrm{OR}=0.18 ; 90 \% \mathrm{CI}=0.04-0.85)$ and the purpose of the vehicle $(\mathrm{OR}=0.20$; $90 \% \mathrm{CI}=0.04-0.94)$ were the significant factors affecting road traffic accidents over the sample period.
\end{abstract}

Keywords: road traffic accidents, risk factors, logistic regression, fatal, non-fatal, Turkey.

\section{Introduction}

Road traffic injuries are one of the leading causes of mortality and disability; about 1.24 million people die each year as a result of road traffic accidents; between 20 to 50 million suffer from non-fatal injuries; and moreover, road traffic accidents are predicted to result in the deaths of 1.9 million people annually by 2020 (WHO, 2013a). Road traffic injuries and fatalities are notably increasing in low-and middle income countries; while current trends suggest that they will become the fifth leading cause of death by 2030, with the disparity between high- and low-income countries. Eighty per cent of road traffic deaths occur in middleincome countries that comprise $72 \%$ of the world's population. Half of the world's all road traffic deaths are among motorcyclists (23\%), pedestrians (22\%), and cyclists (5\%), so-called 'vulnerable road users', and not surprisingly, higher proportion of them are the citizens of low- or middle-income countries (WHO, 2013b).

As a middle-income country in Southeastern Europe, Turkey suffers from traffic accidents and their negative outcomes. There has been an overwhelmingly very large increase in the number of road motor vehicles in Turkey during the last ten years, such that, the

${ }^{1}$ Corresponding author: akemal.celik@atauni.edu.tr 
number of road motor vehicles has increased by approximately $90 \%$ (Turkish National Police, 2013a). In that period, more than 8.8 million road traffic accidents were occurred, almost 1.1 million of them were fatal or nonfatal which affected nearly two millions people. Specifically, 22 to 31 people were killed, and 1,340 to 1,574 people were injured per 100,000 vehicles (Turkish Statistical Institute, 2012a; Turkish National Police, 2013b).

Over the past years, a great number of studies have concentrated on manifold factors influencing fatal and non-fatal road traffic accidents and their injury severity. Recent studies emphasized pre-crash human factors, such as alcohol consumption (Kim et al., 1995; Reynaud et al., 2002; Cummings et al., 2006; Yannis et al., 2008; Arranz and Gil, 2009; De Boni et al., 2013); seat-belt or Helmet usage (Cooper and Salzberg, 1993; Kim et al., 1995; Cummings et al., 2006); pre-crash vehicle factors such as the type of tyres (Strandoth et al., 2012; Elvik et al., 2013); at-crash vehicle factors such tire blow-outs, mechanical defects of the motor vehicles (Martin and Laumon, 2005; Barengo et al., 2006; Alam and Spainhour, 2009); pre-crash environmental factors such as roadway features or defects (Shankar et al., 1995; Karlaftis and Golias, 2002; Lee and Mannering, 2002; Chen and Chen, 2011; Kartal et al., 2011); at crash environmental factors such as road parameters, traffic signs, street lights, curbs or rumble strips (Hijar et al., 2000; Carson and Mannering, 2001; Zhou et al., 2005; Kim et al., 2007; Bombom and Edino, 2009; Šliupas, 2009; Pulugurtha and Bhatt, 2010; Jiang et al.,
2011; Mamčic and Sivilevičius, 2013) using various statistical methods including logistic regression. In some researches, age (Cooper, 1990; Abdel-Aty et al., 1998; Zhang et al., 1998; 2000; Awadzi et al., 2008; Alam and Spainhour, 2009), gender (Ulfarsson and Mannering, 2004; Islam and Mannering, 2006; Bener and Crundall, 2008; Majdzadeh et al., 2008), or both factors (Holubowycz et al., 1994; Massie et al., 1995; Chipman, 1995; Glendon et al., 1996; Laapotti and Keskinen, 1998; Jones and Jørgensen, 2003; Kaplan and Prato, 2012) are examined as specific risk factors.

\section{Materials and Methods}

\subsection{General Traffic Information about Kars City}

Kars is a city located in Northeast Turkey with a population of 304,821 ; an area of 10,127 square kilometers; and an altitude of 1768 meters including its province, 8 districts, and 382 villages (Governor of Kars, 2013). Fig. 1 depicts the road traffic map of the city. Kars city covers 736 kilometers of network length, 675 kilometers of total road including 499 kilometers of national, and 176 kilometers of provincial highway (Republic of Turkey General Directorate of Highways, 2013). As of December, 31, 2012 , there are 94,797 registered drivers and 35,216 motor vehicles in Kars including 14,927 tractors, 9,257 automobiles, 5,854 single-unit trucks, 1,870 trucks, 1,641 minibuses, 1,126 motorcycles, 417 buses, and 129 special-purposed vehicles (Turkish Statistical Institute, 2012b; Turkish National Police, 2013c). 


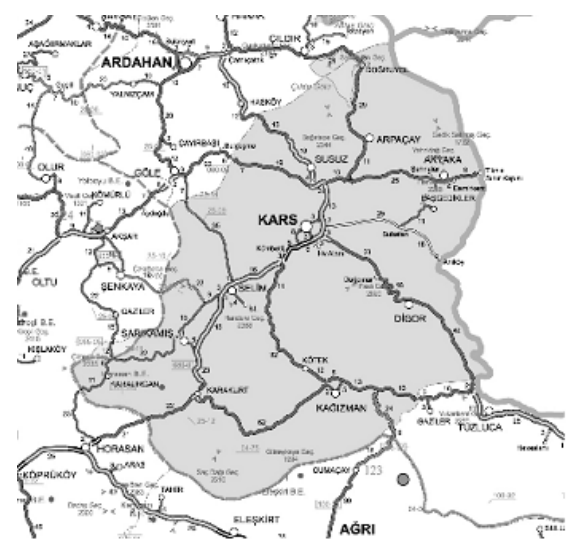

Fig. 1.

Traffic Highway Map of Kars

Source: General Directorate of Highways

The traffic accident data used in this study were obtained from road traffic accident reports of Traffic Services Branch Office and Regional Traffic Control Branch Office under the responsibility of Kars Provincial Police Department. The corresponding data involved 765 fatal and non-fatal road traffic accidents which occurred on Kars city and its central districts' roads during 2008-2012. The paper used a simple random sampling method to investigate the data of 765 traffic police-reported accidents, while the data were transformed and coded to a convenient computer-ready form. A fatal-injury accident is defined as an accident in which at least one person (driver, passenger or pedestrian) was killed at crash. A non-fatal injury accident refers to an accident in which at least one person was suffered injury but no fatalities were occurred.

\subsection{Methods}

Most studies have several explanatory variables, which they may be continuous as well as categorical. In that context, a good- fitting model will evaluate their effects on response variables, will include relevant interactions, and will provide smoothed estimates of response probabilities (Agresti, 2002). While an observation taking one of two possible forms on each individual is supposed, and if for the $i^{\text {th }}$ individual, this observation is represented by a random variable, $y$; then without loss of generality code, two possible values of $y$ by 1 and 0 can be defined as follows (Eq. (1)):

$E(y)=\operatorname{Prob}(y=1)=\pi, \operatorname{Prob}(y=0)=1-\pi$

In Eq. (1), $y=1$ and $y=0$ are usually called a 'success', and 'failure', respectively, and such observations are considered as 'binary' (Cox, 1970).

For a binary response $Y$ and a quantitative independent variable $X$, when $\pi(x)$ denotes the success probability, the logistic regression model has linear form for the logit of the corresponding probability as follows (Eq. (2)): 


$$
g(x)=\log \left(\frac{\pi(x)}{1-\pi(x)}\right)=x_{i} \beta
$$

The left-hand side of Eq. (2) is called the logodds ratio (OR), and the odds of response variable can be derived (Agresti, 1996):

$$
\frac{\pi(x)}{1-\pi(x)}=\exp \left(x_{i} \beta\right)
$$

The odds initially indicate how often something happens relative to how often it does not happen (Long, 1997). The log of the odds transformation performs the conversion of the probability estimates to a continuous unbounded variable. This variable will become the dependent variable in a linear model with the categorical definitions as independent variables (Hanushek and Jackson, 1977). In Eq. (3), for every oneunit increase in $x$, the odds will increase multiplicatively by $e^{\beta}$, namely, the odds at level $x+1$ will equal to the odds at $x$ multiplied by $e^{\beta}$ Specifically, when $\beta=0, e^{\beta}$ will be equal to 1 , and the odds do not change as $x$ changes (Agresti, 1996).

Stepwise logistic regression procedure enables a useful and effective data analysis tool and employing a stepwise procedure can provide a fast and effective means to screen a large number of variables, and to fit a number of logistic regression equations simultaneously. Any stepwise procedure for selection or deletion of variables from a model is based on a statistical algorithm that checks for the importance of variables
(Hosmer and Lemeshow, 2000). In this study, because the dependent variable is a binary or dichotomous variable, the stepwise logistic regression is an appropriate technique, which is developed to predict a binary dependent variable as a function of independent variables. This technique is frequently used in road safety where the dependent variable is binary (Chipman, 1995; Zhang et al., 1998, 2000; Shon and Shin, 2001; Al-Ghamdi, 2002; Reynaud et al., 2002; Jones and Jørgensen, 2003; Yau, 2004; Sze and Wong, 2007; Awadzi et al., 2008; Majdzadeh et al., 2008; Tay et al., 2008; Kartal et al., 2011; De Boni et al., 2013; Drucker et al., 2013).

\section{Results}

This study investigates the effects of twentyone factors on fatal versus non-fatal road traffic accidents in Kars during 2008-2012, as shown in Table 1, which also indicates the mean, standard deviation. In this study, except for age, all variables were qualitative, where age was interpreted as a continuous variable. In order to clarify the results, most of the variables were defined as dummy variables, which take only 0 or 1 . Gender, nationality and seat belt factors were also omitted because of the dominancy of male and Turkish drivers, respectively. The traffic police mentioned that they had any opportunity to recognize the seat-belt status of the driver at crash, and they have coded the status as 'unknown', so security factors were omitted from the model. Similarly, because pedestrians' information was unclear in the reports, it was excluded and only drivers' information was included. 


\section{Table 1}

Descriptive Statistics of Variables

\begin{tabular}{|c|c|c|c|}
\hline Variable & Description & Mean & S.D. \\
\hline Accident type $(\mathrm{Q})$ & Dependent variable $($ non-fatal $=0$; fatal $=1$ ) & 0.029 & 0.167 \\
\hline \multirow{4}{*}{ (1) Season (Q) } & Spring $=1 ;$ Otherwise $=0$ & 0.191 & 0.393 \\
\hline & Summer $=1$; Otherwise $=0$ & 0.277 & 0.448 \\
\hline & Autumn $=1 ;$ Otherwise $=0$ & 0.320 & 0.467 \\
\hline & Winter $=1 ;$ Otherwise $=0$ & 0.212 & 0.409 \\
\hline \multirow[t]{4}{*}{ (2) Hour (Q) } & $00: 00-05: 59=1 ;$ Otherwise $=0$ & 0.065 & 0.247 \\
\hline & $06: 00-11: 59=1 ;$ Otherwise $=0$ & 0.261 & 0.440 \\
\hline & $12: 00-17: 59=1 ;$ Otherwise $=0$ & 0.379 & 0.485 \\
\hline & $18: 00-23: 59=1 ;$ Otherwise $=0$ & 0.294 & 0.456 \\
\hline \multirow[t]{3}{*}{ (3) Weather (Q) } & Clear $=1 ;$ Otherwise $=0$ & 0.668 & 0.471 \\
\hline & Cloudy $/$ Rainy $/$ Foggy $=1$; Otherwise $=0$ & 0.264 & 0.441 \\
\hline & Snowy $/$ Stormy $=1 ;$ Otherwise $=0$ & 0.068 & 0.252 \\
\hline (4) Time of day (Q) & Night time $=1$; Day time $=0$ & 0.357 & 0.479 \\
\hline (5) Site (Q) & Formal settlement $=1$; Informal settlement $=0$ & 0.601 & 0.506 \\
\hline (6) Occurance of accident (Q) & $\begin{array}{l}\text { Overturn/Falling person, animal or object from the vehicle/ } \\
\text { Skidding from the road }=1 \text {; Collision }=0\end{array}$ & 0.461 & 0.499 \\
\hline (7) Number of vehicle(s) (Q) & Single vehicle $=1 ;$ Multi-vehicle $=0$ & 0.361 & 0.481 \\
\hline (8) Divided highway (Q) & Divided highway $=1$; Undivided highway $=0$ & 0.659 & 0.474 \\
\hline \multirow[t]{3}{*}{ (9) Road surface (Q) } & Dry $/$ Dusty $=1$; Otherwise $=0$ & 0.677 & 0.468 \\
\hline & Wet $/$ Puddle $/$ Oil on the pavement $=1 ;$ Otherwise $=0$ & 0.152 & 0.359 \\
\hline & Snowy $/$ Icy $=1$; Otherwise $=0$ & 0.171 & 0.377 \\
\hline (10) Direction of the road (Q) & Two-way $=1$; One-way $=0$ & 0.797 & 0.402 \\
\hline (11) Working on the road (Q) & Available $=1$; not available $=0$ & 0.103 & 0.305 \\
\hline (12) Road lane line (Q) & Available $=1$; not available $=0$ & 0.604 & 0.513 \\
\hline \multirow[t]{3}{*}{ (13) Horizontal route $(\mathrm{Q})$} & Straight road $=1$; otherwise $=0$ & 0.782 & 0.252 \\
\hline & Slight road curve $/$ Bend $=1 ;$ Otherwise $=0$ & 0.180 & 0.385 \\
\hline & $\begin{array}{l}\text { Hard road curve/Bend with or without rail = } 1 \text {; } \\
\text { Otherwise }=0\end{array}$ & 0.038 & 0.191 \\
\hline (14) Vertical route $(Q)$ & Slight slope $/$ Steep slope $/$ Over the hill slope $=1 ;$ No slope $=0$; & 0.363 & 0.481 \\
\hline (15) Side walk (Q) & Available $=1$; not available $=0$ & 0.207 & 0.405 \\
\hline (16) Age (C) & Age of the driver & 36.24 & 10.88 \\
\hline \multirow[t]{4}{*}{ (17) Education level (Q) } & Education level of the driver & & \\
\hline & Primary education $=1 ;$ otherwise $=0$ & 0.492 & 0.500 \\
\hline & Secondary education $=1$; otherwise $=0$ & 0.310 & 0.463 \\
\hline & Higher education $=1$; otherwise $=0$ & 0.199 & 0.399 \\
\hline (18) Alcohol use (Q) & Drunk $=1$; otherwise $=0$ & & \\
\hline \multirow{4}{*}{ (19) Type of vehicle (Q) } & Auto $=1 ;$ otherwise $=0$ & 0.142 & 0.350 \\
\hline & Single-unit truck/truck $/$ bus $=1 ;$ otherwise $=0$ & 0.516 & 0.500 \\
\hline & Others (i.e. motorcycle, tractor, ambulance, military vehicle) & 0.384 & 0.487 \\
\hline & & 0.099 & 0.299 \\
\hline \multirow{4}{*}{ (20) Purpose of vehicle (Q) } & Private $=1$; otherwise $=0$ & & \\
\hline & Commercial $=1$; otherwise $=0$ & 0.724 & 0.447 \\
\hline & Others (i.e. security, military, agricultural) $=1$; & 0.184 & 0.388 \\
\hline & otherwise $=0$ & 0.081 & 0.273 \\
\hline \multirow[t]{2}{*}{ (21) Contributing circumstance (Q) } & Speeding $=1 ;$ otherwise $=0$ & & \\
\hline & Inattention and negligence $=1$; otherwise $=0$ & 0.545 & 0.498 \\
\hline \multirow{2}{*}{$\begin{array}{l}\text { (Q) }=\text { Qualitative variable } \\
\text { C) }=\text { Continuous variable }\end{array}$} & Others (i.e. violating transition rule, rear-end collision/ & 0.184 & 0.388 \\
\hline & $\begin{array}{l}\text { improper lane changing } / \text { lane rape, lack of tecnical } \\
\text { requirements) }=1 \text {; otherwise }=0\end{array}$ & 0.325 & 0.469 \\
\hline
\end{tabular}

(Q) = Qualitative variable

(C) = Continuous variable 
Table 2

Logistic Regression Estimation Results of Risk Factors Affecting Fatal vs Non-Fatal Road Traffic Accidents

\begin{tabular}{|c|c|c|c|c|c|}
\hline Variable & OR & Std. Err. & $\mathbf{Z}$ & p-value & [90\% C.I. $]$ \\
\hline (1) Season (base Spring) & 0.41 & 0.307 & -1.19 & 0.234 & \\
\hline Summer & 0.38 & 0.263 & -1.40 & 0.162 & $0.12-1.40$ \\
\hline Autumn & 0.16 & 0.148 & -1.95 & $0.052^{* * *}$ & $0.12-1.19$ \\
\hline Winter & & & & & $0.03-0.75$ \\
\hline (2) Hour (base 00:00 - 05:59) & 0.93 & 1.325 & -0.05 & 0.959 & \\
\hline $06: 00-11: 59$ & 0.32 & 0.427 & -0.86 & 0.392 & $0.09-9.72$ \\
\hline $12: 00-17: 59$ & 0.43 & 0.442 & -0.82 & 0.411 & $0.04-2.85$ \\
\hline $18: 00-23: 59$ & & & & & $0.08-2.33$ \\
\hline (3) Weather (base Snowy/Stormy) & 0.11 & 0.120 & -2.04 & $0.041^{* *}$ & \\
\hline Clear & 0.50 & 0.503 & -0.69 & 0.490 & $0.02-0.65$ \\
\hline Cloudy/Rainy/Foggy & & & & & $0.09-2.63$ \\
\hline (4) Time of day & 2.21 & 2.137 & 0.82 & 0.413 & \\
\hline Night Time & & & & & $0.45-10.9$ \\
\hline (5) Site & 0.99 & 0.752 & -0.01 & 0.995 & \\
\hline Formal Settlement & & & & & $0.29-3.45$ \\
\hline (6) Occurance of accident & 0.34 & 0.276 & -1.33 & 0.184 & \\
\hline $\begin{array}{l}\text { Overturn/Falling person, animal or object from the vehicle/ } \\
\text { Skidding from the road }\end{array}$ & & & & & $0.09-1.29$ \\
\hline (7) Number of vehicle(s) & 1.67 & 1.717 & 0.50 & 0.620 & \\
\hline Single vehicle & & & & & $0.31-9.07$ \\
\hline (8) Divided highway & 2.13 & 1.453 & 1.11 & 0.266 & \\
\hline Divided Highway & & & & & $0.70-6.54$ \\
\hline (9) Road surface (base Wet/Oil on the Pavement) & 1.55 & 1.611 & 0.43 & 0.670 & \\
\hline Dry/Dusty & 0.40 & 0.509 & -0.72 & 0.472 & $0.28-8.55$ \\
\hline Snowy/Icy & & & & & $0.05-3.24$ \\
\hline (10) Direction of the road & 0.41 & 0.319 & -1.15 & 0.252 & \\
\hline Two-way & & & & & $0.11-1.48$ \\
\hline (11) Work on the road & 0.66 & 0.760 & -0.36 & 0.720 & \\
\hline Available & & & & & $0.10-4.37$ \\
\hline (12) Road lane line & 1.87 & 1.103 & 1.07 & 0.286 & \\
\hline $\begin{array}{l}\text { Available } \\
\text { (13) Horizontal route (base Hard road curve/Bend with or } \\
\text { without rail) }\end{array}$ & & & & & $0.71-4.93$ \\
\hline Straight road & 0.22 & 0.189 & -1.76 & $0.078^{* * *}$ & \\
\hline Slight road curve/bend & 0.17 & 0.165 & -1.85 & $0.065^{* * *}$ & $0.05-0.91$ \\
\hline (14) Vertical route & & & & & $0.04-0.83$ \\
\hline Slight slope/Steep slope/Over the hill slope & 2.71 & 1.731 & 1.56 & 0.118 & \\
\hline (15) Side walk & & & & & $0.95-7.75$ \\
\hline Available & 0.19 & 00 & -1.10 & 0.273 & \\
\hline (16) Age & 1.09 & 0.287 & 3.67 & $0.000^{*}$ & $0.02-2.30$ \\
\hline (17) Education level(base Higher Education) & & 01 & & & $1.05-1.14$ \\
\hline Primary education & 0.39 & 0.027 & -1.25 & 0.210 & \\
\hline Secondary education & 0.18 & & -1.82 & $0.069^{* * *}$ & $0.12-1.34$ \\
\hline (18) Alcohol use & & 0.293 & & & $0.04-0.85$ \\
\hline Drunk & 1.80 & 0.171 & 0.71 & 0.476 & \\
\hline (19) Type of vehicle (base Others) & & & & & $0.47-6.92$ \\
\hline Auto & 2.34 & 1.473 & 0.80 & 0.422 & \\
\hline Single-unit truck/truck/bus & 3.66 & & 1.26 & 0.207 & $0.41-13.3$ \\
\hline (20) Purpose of vehicle (base Others) & & 2.471 & & & $0.67-19.8$ \\
\hline Private & 0.20 & 3.767 & -1.71 & $0.088^{* * *}$ & \\
\hline Commercial & 0.27 & & -1.23 & 0.217 & $0.04-0.94$ \\
\hline (21) Contributing circumstance (base Others) & & 0.188 & & & $0.05-1.55$ \\
\hline Speeding & 2.15 & 0.286 & 0.75 & 0.454 & \\
\hline Inattention and negligence & 2.39 & & 0.82 & 0.411 & $0.40-11.6$ \\
\hline Number of observations $=765$ & & 2.208 & & & $0.42-13.7$ \\
\hline Log likelihood $=-71.163$ & & 2.533 & & & \\
\hline Logistic regression $X^{2}=57.18$ & & & & & \\
\hline Prob $>X^{2}=0.0056$ & & 1 & & & \\
\hline Pseudo $R^{2}=0.2866$ & & & & & \\
\hline
\end{tabular}

${ }^{*}$ Significant at $1 \%$ level ${ }^{* *}$ Significant at $5 \%$ level ${ }^{* *}$ Significant at $5 \%$ level 
Table 2 indicates the estimation results for the final stepwise logistic regression model. Based on p-values, 7 variables from 24 factors were found to be significant or marginally significant. Number of observations was 765 , with a $\log$ likelihood value of -71.163 and chi-square was equal to 57.18. As shown in Table 2, fatal road traffic accidents in Kars were more likely to occur with respect to the driver's age $(\mathrm{OR}=1.09 ; 90 \% \mathrm{CI}=1.05$ - 1.14), where the corresponding variable was marginally significant. Fatal road traffic accidents were $89 \%$ less likely to occur when the weather was clear (OR = $0.11 ; 90 \% \mathrm{CI}=0.02-0.65)$. Additionally, fatal traffic accidents were $84 \%$ less likely to occur in winter $(\mathrm{OR}=0.16 ; 90 \% \mathrm{CI}=$ $0.03-0.75)$. Kars has a continental climate and the weather is usually rainy or snowy throughout the year, even in the spring and summer, for that reason vehicles are also well-prepared for the negative effects of the weather conditions. In that context, the impacts of season and weather factors on the occurrence of fatal and non-fatal road traffic accidents are not surprising.

The results showed that horizontal route factor had an impact on the probability of fatal and non-fatal road traffic accidents. Herein, when an accident was occurred at straight road $(\mathrm{OR}=0.22 ; 90 \% \mathrm{CI}=0.05$ 0.91 ) or slight road curve/bend ( $\mathrm{OR}=0.17$; $90 \%$ CI $=0.04-0.83$ ), it was less likely to occur a fatal accident. Furthermore, the driver's education level had impact on the probability of occurrence of fatal road traffic accidents. They were less likely to occur when the driver's education level was secondary $(\mathrm{OR}=0.18 ; 90 \% \mathrm{CI}$ $=0.04-0.85)$. The results also showed the significant impact of the purpose of the vehicle $(\mathrm{OR}=0.20 ; 90 \% \mathrm{CI}=0.04$ 0.94) on fatal versus non-fatal road traffic accidents. One unit increase in private vehicle variable had a 0.20 decreasing impact on the likelihood of fatal accidents against non-fatal accidents.

The variance inflation factor (VIF) facilitates to measure how much multicollinearity has increased the variance of a slope estimate (Stine, 1995). In practice, since VIF is less than 10 , the researchers can suggest that no variables cause the multicollinearity problem in the analysis. In Table 3, VIF values of independent variables used in this study were presented to ensure that there was not a multicollinearity problem among these independent variables, where all VIF values, including the mean VIF, are less than 10 . 


\section{Table 3}

Variance Inflation Factors of Independent Variables

\begin{tabular}{|c|c|c|}
\hline Variable & VIF & 1/VIF \\
\hline \multicolumn{3}{|l|}{ (1) Season } \\
\hline Summer & 1.94 & 0.515 \\
\hline Autumn & 1.97 & 0.509 \\
\hline Winter & 2.26 & 0.442 \\
\hline \multicolumn{3}{|l|}{ (2) Time } \\
\hline $06: 00-11: 59$ & 6.87 & 0.146 \\
\hline $12: 00-17: 59$ & 7.24 & 0.138 \\
\hline 18:00-23:59 & 4.35 & 0.230 \\
\hline \multicolumn{3}{|l|}{ (3) Weather } \\
\hline Clear & 5.70 & 0.175 \\
\hline $\begin{array}{l}\text { Cloudy/Rainy/Foggy } \\
\text { (4) Time of day }\end{array}$ & 5.14 & 0.195 \\
\hline $\begin{array}{l}\text { Night Time } \\
\text { (5) Site }\end{array}$ & 3.10 & 0.323 \\
\hline $\begin{array}{l}\text { Formal Settlement } \\
\text { (6) Occurance of accident }\end{array}$ & 2.25 & 0.445 \\
\hline $\begin{array}{l}\text { Overturn/Falling person, animal or object from the vehicle/Skidding from the road } \\
\text { ( } 7 \text { ) Number of vehicle(s) }\end{array}$ & 2.41 & 0.415 \\
\hline $\begin{array}{l}\text { Single vehicle } \\
\text { (8) Divided highway }\end{array}$ & 3.57 & 0.280 \\
\hline $\begin{array}{l}\text { Divided Highway } \\
\text { (9) Road surface (base Wet/Oil on the Pavement) }\end{array}$ & 1.75 & 0.571 \\
\hline Dry/Dusty & 3.70 & 0.270 \\
\hline $\begin{array}{l}\text { Snowy/Icy } \\
\text { (10) Direction of the road }\end{array}$ & 2.87 & 0.348 \\
\hline $\begin{array}{l}\text { Two-way } \\
\text { (11) Work on the road }\end{array}$ & 1.61 & 0.622 \\
\hline $\begin{array}{l}\text { Available } \\
\text { (12) Road lane line }\end{array}$ & 1.16 & 0.863 \\
\hline $\begin{array}{l}\text { Available } \\
\text { (13) Horizontal route (base Hard road curve/Bend with or without rail) }\end{array}$ & 1.53 & 0.655 \\
\hline Straight road & 5.34 & 0.187 \\
\hline $\begin{array}{l}\text { Slight road curve/bend } \\
\text { (14) Vertical route }\end{array}$ & 4.89 & 0.204 \\
\hline $\begin{array}{l}\text { Slight slope/Steep slope/Over the hill slope } \\
\text { (15) Side walk }\end{array}$ & 1.51 & 0.664 \\
\hline Available & 2.05 & 0.489 \\
\hline $\begin{array}{l}\text { (16) Age } \\
\text { (17) Education level(base Higher Education) }\end{array}$ & 1.15 & 0.871 \\
\hline $\begin{array}{l}\text { (17) Education level(base Higher Education) } \\
\text { Primary education }\end{array}$ & 2.17 & 0.460 \\
\hline $\begin{array}{l}\text { Secondary education } \\
\text { (18) Alcohol use }\end{array}$ & 1.95 & 0.513 \\
\hline $\begin{array}{l}\text { Drunk } \\
\text { (19) Type of vehicle (base Others) }\end{array}$ & 1.24 & 0.806 \\
\hline Auto & 4.47 & 0.224 \\
\hline $\begin{array}{l}\text { Single-unit truck/truck/bus } \\
\text { (20) Purpose of vehicle (base Others) }\end{array}$ & 4.18 & 0.239 \\
\hline Private & 3.59 & 0.279 \\
\hline $\begin{array}{l}\text { Commercial } \\
\text { (21) Contributing circumstance (base Others) }\end{array}$ & 3.33 & 0.300 \\
\hline Speeding & 3.68 & 0.272 \\
\hline Inattention and negligence & 2.04 & 0.489 \\
\hline Mean VIF & 3.12 & \\
\hline
\end{tabular}


Table 4

Goodness of Fit Statistics

\begin{tabular}{ll}
\hline Number of observations & 765 \\
Number of covariate patterns & 758 \\
Pearson $\mathrm{X}^{2}(724)$ & 405.88 \\
Hosmer-Lemeshow $\mathrm{X}^{2}(8)$ & 2.16 \\
Prob $>\mathrm{X}^{2}$ & 0.98 \\
\hline
\end{tabular}

\section{Conclusion}

The Eastern regions of Turkey are relatively underdeveloped and exposed to chronic economic and financial problems. In recent years, automobiles and various types of trucks had also produced in the occurrence of fatal and/or non-fatal road traffic accidents. The great number of motor vehicles involved in the road traffic is one of the common issues of traffic safety in Turkey and the rural regions. Otherwise, Kars city suffers from unfavorable weather conditions; where average number of rainy days exceeds ten days in a month with average total amount of rainfall ranging between 20.3 and 77.2 kilograms/square meters in a year. In addition, as a result of continental climate, Kars city is one of the coldest cities in Turkey, such that the number of snowy days exceeds 120 days (Turkish State Meteorological Service, 2013). In that context, weather conditions tend to negatively affect fatal and/or non-fatal road traffic accidents.

By the courtesy of various regional development projects and Turkish governors' dominancy, roadways and the road traffic have been remarkably improved during the last five years in Northeast Turkey. However, there are still significant regional disparities between the West and the East. The Eastern regions survive with economic difficulties that inherently have an impact on the road traffic. Despite optimistic development efforts, the corresponding territories still need qualified roadways to overcome the lack of countrywide essential transition. Decision makers should concentrate on more durable roadway construction ventures, namely, asphalts and other traffic infrastructures do not negatively affected by weather conditions in a little while. From a different perspective, more educated traffic personnel and conscious drivers will be probably helpful to create a more favorable traffic environment.

According to the results of this study, age variable was highlighted as a marginally significant risk factor affecting fatal road traffic accident against non-fatal. Since driver's age particularly increases the probability of occurrence for fatal road traffic accidents, the crucial roles of both policy makers and young drivers' parents revisit. In this sense, parents may preemptively avoid adolescents to drive before permitted by the relevant legislation. Similarly, traffic security laws may be re-arranged by deterrent regulations to preclude the satisfaction of inexperienced young drivers. Since most of the traffic users properly respect traffic safety regulations, an important step may be surpassed. Nevertheless, decision makers should draw attention to the poor reporting of road traffic accidents. For instance, risk factors such as seat belt and alcohol use of the traffic users should be more efficiently reported to determine the virtual reasons of the road traffic accidents more precisely. On the other hand, road traffic accidents in Turkey are considered as fatal accidents when one of the traffic users is fatally injured when the accident occurs and the elapsed time period in the hospital is ignored in contrast to the procedure applied in many developed countries. In that circumstance, the number of actual fatally injured traffic users is not properly illustrated. Emerging countries should adapt their traffic legislation 
to developed countries to reach better traffic reporting standards and thus achieving an improved traffic safety policy.

\section{Acknowledgements}

The authors would like to thank Kars Provincial Traffic Police Department, especially Traffic Services Branch and Regional Traffic Control Branch Offices' chief superintendents and all the staff for their supports, special interests, and courtesy in charge of collecting nonpersonalized data and advice on data management that made this study possible.

\section{References}

Abdel-Aty, M.A.; Chen, C.L.; Schott, J.R. 1998. An assessment of the effect of driver age on traffic accident involvement using log-linear models, Accident Analysis \& Prevention. DOI: http://dx.doi.org/10.1016/S00014575(98)00038-4, 30(6): 851-861.

Agresti, A. 1996. An Introduction to Categorical Data Analysis. John Wiley \& Sons, Inc. USA. 400 p.

Agresti, A. 2002. Categorical Data Analysis. John Wiley \& Sons, Inc. USA. 744 p.

Alam, B.M.; Spainhour, L.K. 2009. Contributing factors for young at fault drivers in fatal traffic crashes in Florida, Journal of Transportation Safety \& Security. DOI: http:// dx.doi.org/10.1080/19439960902735444, 1(2): 152-168.

Al-Ghamdi, A.S. 2002. Using logistic regression to estimate the influence of accident factors on accident severity, Accident Analysis \& Prevention. DOI: http:// dx.doi.org/10.1016/S0001-4575(01)00073-2, 34(6): 729-741.

Arranz, J.M.; Gil, A.I. 2009. Traffic accidents, deaths and alcohol consumption, Applied Economics. DOI: http:// dx.doi.org/10.1080/00036840701222652, 41(20): 2583-2595.
Awadzi, K.D.; Classen, S.; Hall, A.; Duncan, R.P.; Garvan, C.W. 2008. Predictors of injury among younger and older adults in fatal motor vehicle crashes, Accident Analysis \& Prevention. DOI: http://dx.doi.org/10.1016/j. aap.2008.07.010, 40(6): 1804-1810.

Barengo, N.C.; Mkamba, S.M.; Mshana, M.; Miettola, J. 2006. Road traffic accidents in Dar-es-Salaam, Tanzania during 1999 and 2001, International Journal of Injury Control and Safety Promotion. DOI: http://dx.doi. org/10.1080/15660970500036713, 13(1): 52-54.

Bener, A.; Crundall, D. 2008. Role of gender and driver behaviour in road traffic crashes, International Journal of Crashworthiness. DOI: http://dx.doi. org/10.1080/13588260801942684, 13(3): 331-336.

Bombom, L.S.; Edino, M.O. 2009. Road profiling of traffic accidents in Jos, Nigeria, 1995-1999, International Journal of Injury Control and Prevention. DOI: http:// dx.doi.org/10.1080/17457300903024186, 16(3): 169-174.

Carson, J.; Mannering, F. 2001. The effect of ice warning signs on ice-accident frequencies and severities, Accident Analysis \& Prevention. DOI: http://dx.doi.org/10.1016/ S0001-4575(00)00020-8, 33(1): 99-109.

Chen, F.; Chen, S. 2011. Injury severities of truck drivers in single- and multi-vehicle accidents on rural highways, Accident Analysis \& Prevention. DOI: http:// dx.doi.org/10.1016/j.aap.2011.03.026, 43(5): 16771688 .

Chipman, M.L. 1995. Risk factors for injury: Similarities and differences for traffic crashes and other causes, Accident Analysis \& Prevention. DOI: http://dx.doi. org/10.1016/0001-4575(95)00013-P, 27(5): 699-706.

Cooper, P.J. 1990. Differences in accident characteristics among elderly drivers and between elderly and middleaged drivers, Accident Analysis \& Prevention. DOI: http:// dx.doi.org/10.1016/0001-4575(90)90044-L, 22(5): 499-508. 
Cooper, P.J.; Salzberg, P. 1993. Safety restraint usage in fatal motor vehicle crashes, Accident Analysis \& Prevention. DOI: http://dx.doi.org/10.1016/00014575(93)90097-G, 25(1): 67-75.

Cox, D.R. 1970. Analysis of Binary Data. Chapman \& Hall Ltd. UK. 142 p.

Cummings, P.; Rivara, F.P.; Olson, C.M.; Smith, K.M. 2006. Changes in traffic crash mortality rates attributed to use of alcohol, or lack of a seat-belt, air bag, motorcycle helmet, or bicycle helmet, United States, 1982-2001, Injury Prevention. DOI: http://dx.doi.org/10.1136/ ip.2005.010975, 12(3): 148-154.

De Boni, R.; Cruz, O.G.; Weber, E.; Hasenack, H.; Lucatelli, L.; Duarte, P.; Gracie, R.; Pechansky, F.; Bastos, F.I. 2013. Traffic crashes and alcohol outlets in a Brazilian state capital, Traffic Injury Prevention. DOI: http://dx.doi.org/10.1080/15389588.2012.690164 , 14(1): 86-91.

Drucker, C.; Gerberich, S.G.; Manser, M.P.; Alexander, B.H.; Church, T.R.; Dyan, A.D.; Becic, E. 2013. Factors associated with civilian drivers involved in crashes with emergency vehicles, Accident Analysis \& Prevention. DOI: http://dx.doi.org/10.1016/j.aap.2013.02.035, 55: 116-123.

Elvik, R.; Fridstrøm, L.; Kaminska, J.; Meyer, S.F. 2013. Effects on accidents of changes in the use of studded tyres in major cities in Norway: A long-term investigation, Accident Analysis \& Prevention. DOI: http:// dx.doi.org/10.1016/j.aap.2013.02.004, 54: 15-25.

Glendon, A.I.; Dorn, L.; Davies, D.R.; Matthews, G.; Taylor, R.G. 1996. Age and gender differences in perceived accident likelihood and driver competences, Risk Analysis. DOI: http://dx.doi.org/10.1111/j.1539-6924.1996. tb00826.x, 16(6): 755-762.

Governor of Kars. 2013. Geographical framework of Kars. Available from Internet: <http://www.kars.gov. tr/kars_cografi_yapi.html $>$.
Hanushek, E.A.; Jackson, J.E. 1977. Statistical Methods for Social Scientists. Academic Press, Inc. USA. 374 p.

Hijar, M.; Carrillo, C.; Flores, M.; Anaya, R.; Lopez, V. 2000. Risk factors in highway accidents: A case control study, Accident Analysis \& Prevention. DOI: http://dx.doi. org/10.1016/S0001-4575(99)00116-5, 32(5): 703-709.

Holubowycz, O.T.; Kloeden, C.N.; McLean, A.J. 1994. Age, sex, and blood alcohol concentration of killed and injured drivers, riders, and passengers, Accident Analysis \& Prevention. DOI: http://dx.doi.org/10.1016/00014575(94)90039-6, 26(4): 483-492.

Hosmer, D.W.; Lemeshow, S. 2000. Applied Logistic Regression. John Wiley \& Sons, Inc. USA. 375 p.

Islam, S.; Mannering, F. 2006. Driver aging and its effect on male and female single-vehicle accident injuries: Some additional evidence, Journal of Safety Research. DOI: http://dx.doi.org/10.1016/j.jsr.2006.04.003, 37(3): 267-276.

Jiang, X.; Yan, X.; Huang, B.; Richards, S.H. 2011. Influence of curbs on traffic crash frequency on highspeed roadways, Traffic Injury Prevention. DOI: http:// dx.doi.org/10.1080/15389588.2011.578285, 12(4): 412-421.

Jones, A.P.; Jørgensen, S.H. 2003. The use of multilevel models for the prediction of road accident outcomes, Accident Analysis \& Prevention. DOI: http://dx.doi. org/10.1016/S0001-4575(01)00086-0, 35(1): 59-69.

Kaplan, S.; Prato, C.G. 2012. Associating crash avoidance maneuvers with driver attributes and accident characteristics: A mixed logit model approach, Traffic Injury Prevention. DOI: http://dx.doi.org/10.1080/153 89588.2011.654015, 13(3): 315-326.

Karlaftis, M.G.; Golias, I. 2002. Effects of road geometry and traffic volumes on rural roadway accident rates, Accident Analysis \& Prevention. DOI: http://dx.doi. org/10.1016/S0001-4575(01)00033-1, 34(3): 357-365.

\section{jitte 349}


Kartal, M.; Kutlar, A.; Begen, A. 2011. Logistic regression analysis of risk factors affecting traffic accidents: Study of Sivas, Kayseri and Yozgat (trans. from Turkish), The International Journal of Economic and Social Research, 7(2): 45-68.

Kim, K.; Nitz, L.; Richardson, J.; Li, L. 1995. Personal and behavioral predictors of automobile crash and injury severity, Accident Analysis \& Prevention. DOI: http://dx.doi. org/10.1016/0001-4575(95)00001-G, 27(4): 469-481.

Kim, J.K.; Kim, S.; Ulfarsson, G.F.; Porello, L.A. 2007. Bicyclist injury severities in bicycle-motor vehicle accidents, Accident Analysis \& Prevention. DOI: http:// dx.doi.org/10.1016/j.aap.2006.07.002, 39(2): 238-251.

Laapotti, S.; Keskinen, E. 1998. Differences in fatal loss-of-control accidents between young male and female drivers, Accident Analysis \& Prevention. DOI: http://dx.doi. org/10.1016/S0001-4575(97)00121-8, 30(4): 435-442.

Lee, J.; Mannering, F. 2002. Impact of roadside features on the frequency and severity of run-off-roadway accidents: an empirical analysis, Accident Analysis \& Prevention. DOI: http://dx.doi.org/10.1016/S00014575(01)00009-4, 34(2): 149-161.

Long, S. 1997. Regression Models for Categorical and Limited Dependent Variables. SAGE Publications. UK. 297 p.

Majdzadeh, R.; Khalagi, K.; Naraghi, K.; Motevalian, A.; Eshraghian, M.R. 2008. Determinants of traffic injuries in drivers and motorcyclists involved in an accident, Accident Analysis \& Prevention. DOI: http:// dx.doi.org/10.1016/j.aap.2007.03.019, 40(1): 17-23.

Mamčic, S.; Sivilevičius, H. 2013. The analysis of traffic accidents on Lithuanian regional gravel roads, Transport. DOI: http://dx.doi.org/10.3846/16484142.2013.7828 94, 28(1): 108-115.

Martin, J.; Laumon, B. 2005. Tire blow-outs and motorway accidents, Traffic Injury Prevention. DOI: http:// dx.doi.org/10.1080/15389580490510174, 6(1): 53-55.
Massie, D.L.; Campbell, K.L.; Williams, A.F. 1995. Traffic accident involvement rates by driver age and gender, Accident Analysis \& Prevention. DOI: http:// dx.doi.org/10.1016/0001-4575(94)00050-V, 27(1): 73-87.

Pulugurtha, S.S.; Bhatt, J. 2010. Evaluating the role of weaving section characteristics and traffic on crashes in weaving areas, Traffic Injury Prevention. DOI: http:// dx.doi.org/10.1080/15389580903370039, 11(1): 104113.

Republic of Turkey General Directorate of Highways. 2013. Road Network of $18^{\text {th }}$ Regional Directorate. Available from Internet: <http://www.kgm.gov.tr>.

Reynaud, M.; Le Breton, P.; Gilot, B.; Vervialle, F.; Falissard, B. 2002. Alcohol is the main factor in excess traffic accident fatalities in France, Alcoholism: Clinical and Experimental Research. DOI: http://dx.doi. org/10.1111/j.1530-0277.2002.tb02490.x, 26(12): 1833-1839.

Shankar, V.; Mannering, F.; Barfield, W. 1995. Effect of roadway geometrics and environmental factors on rural freeway accident frequencies, Accident Analysis \& Prevention. DOI: http://dx.doi.org/10.1016/00014575(94)00078-Z, 27(3): 371-389.

Shon, S.Y.; Shin, H. 2001. Pattern recognition for road traffic accident severity in Korea, Ergonomics. DOI: http://dx.doi.org/10.1080/00140130120928, 44(1): 107-117.

Šliupas, T. 2009. The impact of road parameters and the surrounding area on traffic accidents, Transport. DOI: http://dx.doi.org/10.3846/1648-4142.2009.24.42-47, 24(1): 42-47.

Stine, R.A. 1995. Graphical interpretation of variance inflation factors, The American Statistician. DOI: http:// dx.doi.org/10.1080/00031305.1995.10476113, 49(1): 53-56. 
Strandroth, J.; Rizzi, M.; Olai, M.; Lie, A.; Tingvall, C. 2012. The effects of studded tires on fatal crashes with passenger cars and the benefits of electronic stability control (ESC) in Swedish winter driving, Accident Analysis \& Prevention. DOI: http://dx.doi.org/10.1016/j. aap.2011.11.005, 45: 50-60.

Sze, N.N.; Wong, S.C. 2007. Diagnostic analysis of the logistic model for pedestrian injury severity in traffic crashes, Accident Analysis \& Prevention. DOI: http://dx.doi. org/10.1016/j.aap.2007.03.017, 39(6): 1267-1278.

Tay, R.; Rifaat, R.M.; Chin, H.C. 2008. A logistic model of the effects of roadway, environmental, vehicle, crash and driver characteristics on hit-and-run crashes, Accident Analysis \& Prevention. DOI: http://dx.doi.org/10.1016/j. aap.2008.02.003, 40(4): 1330-1336.

Turkish State Meteorological Service. 2013. Official Statistics of Provinces and Districts. Available from Internet: <http://www.mgm.gov.tr/veridegerlendirme/ il-ve-ilceler-istatistik.aspx?m=KARS $>$.

Turkish Statistical Institute. 2012a. Traffic accident statistics (Road) 2011. Available from Internet: <www. tuik.gov.tr/IcerikGetir.do?istab_id=70>.

Turkish Statistical Institute. 2012b. Road motor vehicle statistics, News Bulletin, October 2012. Available from Internet: <http://www.tuik.gov.tr/PreHaberBultenleri. do?id=10965 $>$.

Turkish National Police. 2013a. Burden of the type of motor vehicles. Available from Internet: $<$ http://www. trafik.gov.tr/Sayfalar/Istatistikler/aracsurucu4.aspx $>$.

Turkish National Police. 2013b. General Traffic Accident Statistics. Available from Internet: <http://www.trafik. gov.tr/Sayfalar/Istatistikler/Genel-Kaza.aspx $>$.

Turkish National Police. 2013c. Burden of the number of drivers with respect to provinces. Available from Internet: <http://www.trafik.gov.tr/Sayfalar/ Istatistikler/aracSurucu1.aspx $>$.
Ulfarsson, G.F.; Mannering, F.L. 2004. Differences in male and female injury severities in sport-utility vehicle, minivan, pickup and passenger car accidents, Accident Analysis \& Prevention. DOI: http://dx.doi.org/10.1016/ S0001-4575(02)00135-5, 36(2): 135-147.

World Health Organization. 2013a. Road traffic injuries. Fact Sheet $\mathrm{N}^{\circ} 358$. Available from Internet: <http:// www.who.int/mediacentre/factsheets/fs358/en/>.

World Health Organization. 2013b. Global status report on road safety 2013: Supporting a decade of action, Geneva, Switzerland: World Health Organization.

Yannis, G.; Papadimitrou, E.; Antoniou, C. 2008. Impact of enforcement on traffic accidents and fatalities: A multivariate multilevel analysis, Safety Science. DOI: http://dx.doi.org/10.1016/j.ssci.2007.01.014, 46(5): 738-750.

Yau, K.K.W. 2004. Risk factors affecting the severity of single vehicle traffic accidents in Hong Kong, Accident Analysis \& Prevention. DOI: http://dx.doi.org/10.1016/ S0001-4575(03)00012-5, 36(3): 333-340.

Zhang, J.; Fraser, S.; Lindsay, J.; Clarke, K.; Mao, Y. 1998. Age-specific patterns of factors related to fatal motor vehicle traffic crashes: Focus on young and elderly drivers, Public Health. DOI: http://dx.doi.org/10.1038/ sj.ph.1900485, 112(5): 289-295.

Zhang, J.; Lindsay, J.; Clarke, K.; Robbins, G.; Mao, Y. 2000. Factors affecting the severity of motor vehicle traffic crashes involving elderly drivers in Ontario, Accident Analysis \& Prevention. DOI: http:// dx.doi.org/10.1016/S0001-4575(99)00039-1, 32(1): 117-125.

Zhou, J.; Zhao, X.; Jiang, Z.; Zhu, S.; Zhou, J. 2005. Investigation on road traffic safety of the mountain areas in Southwest China based on Wulong county, Chongqing Municipality, Traffic Injury Prevention. DOI: http://dx.doi.org/10.1080/15389580590931707, 6(2): 193-196.

\section{jitte 351}

